\title{
A Study on Consumer Empathic Response to Advertising Expressions: Focusing on Mobile Storytelling Video Advertising
}

\author{
Kang Zou ${ }^{1}$ and Dong Wang ${ }^{2 *}$ \\ ${ }^{1}$ Department of Refrigeration and Air-Conditioning Engineering, Tongmyong \\ University, Korea \\ ${ }^{2}$ Department of Visual Design, Tongmyong University, Korea \\ ${ }^{1}$ zoukang116@naver.com, ${ }^{2}$ wangdong2028@naver.com
}

\begin{abstract}
With the sudden change of new media environment, the consumer's new media use behavior has changed entirely. Today, consumers do not evaluate the products' function and quality which enterprise has. They choose by the story which it involves. And the importance and value of the story is becoming bigger than any period. Now the mobile storytelling video advertisement is the advertisement media which has the biggest influence. Further, mobile storytelling video advertisement makes sympathy stronger than the plane media with conversation, music, plot, and so on various forms of expression. To this, the research searches the mobile storytelling video advertisement's concept and characteristic, and makes it as the foundation. It analyzes the consumer's sympathy response by brain wave experiment and question investigation in mobile storytelling video advertisement and expression type. It is to analyze that if there is possibility for the sympathy response to contribute to advertisement effect and prediction.
\end{abstract}

Keywords: Mobile storytelling video advertisement, expression type, consumer, empathic response 


\section{Introduction}

\subsection{Background and purpose of study}

Digital advertising has been expanded to the areas of advertising and media by means of smart technology. In addition, through the linkage of commerce contents, it is creating a new area of advertising market that seemed to be unachievable in the previous mobile or internet-based advertising environment. In Korea, mobile usage style is overly concentrated on mobile apps, with $91.1 \%$ of the total usage time of mobile apps. Therefore, it is necessary to pay attention to whether mobile video advertising can lead to innovative growth that creates a new video advertising with image technology and various IT combined while driving quantitative growth throughout the market.

The method attracting attention in recent academic and practical studies is storytelling that appeals to consumers' emotions (MalKum et al., 2016). Today, video advertisements based on storytelling, which have been converted into mobile forms, have secured many consumers. Especially, as the trend in the market changes from the rational consumption to the emotional consumption, the role of emotional advertisement using 'digilog marketing' is expanding (HeeLee, 2016).

This study examines the mobile storytelling video advertisement through the review of the literature based on these perspectives above. Mobile storytelling video advertising as the most influential advertising method, it takes on a role in promoting products, plays an important role in expanding brands, and communicates with consumers along with flat media. In addition, mobile storytelling video advertisements are deriving more empathy from consumers than flat media through various expression forms such as dialogue, plot, and music. So, what part of mobile storytelling video advertising draws empathy from consumers? I wonder how much of the influence it will be. To get answers to these parts, there is a need to examine the study of previous studies first. In addition, for more scientific and in-depth investigation, this study will record brain activity through brain wave test through digital EEG measurement, and analyze this study based on the scientific data drawn. Although there are many practical and valuable studies on digital storytelling advertisements, there are not enough studies on new concepts of composition in academic terms. Especially, still insufficient is the research on the advertising effect and the empathy of consumers about the type of expression in storytelling advertisement suitable for digital and mobile environment. Under the recognition of the lack of academic research on the practical value, this study attempts to explore the role of empathic response to the effects of storytelling advertisements.

First, this study examines the concept and characteristics of mobile storytelling video advertisement, and based on these, analyzes the factors that cause consumer's empathy in the types of expression through brain wave experiments and surveys. Also, this study examines whether there is a possibility of predictability in terms of 
the advertising effect through the empathic response of consumers.

The biggest characteristic of mobile storytelling video advertising is that it delivers a convincing story to consumers and draws empathic responses from consumers. Therefore, the expression type conveying the story convincingly and effectively is especially important in storytelling video advertisement. Namely, the purpose of this study is to suggest guidelines for establishing new advertising strategies that both companies and consumers can satisfy in establishing strategies for mobile storytelling video advertising by grasping these expression types.

The specific objects of research are as follows.

Research Question 1: What kind of empathy does the expression type of mobile storytelling video advertisement cause to consumers?

Research Question 2: What brain wave response will be shown in the video advertisement of mobile storytelling in terms of cognitive empathy, emotional empathy, emotional empathy and authentic empathy?

\subsection{Research scope and method}

As a type of mobile storytelling video advertisement, storytelling video advertisements were collected for four years from 2014 to 2017.

Through FGI(Fous Group Interview, 2005) target group interview method, A total of 25 advertisements were selected that recorded more than one million views by five items, among which one advertisement chosen by an expert group was selected as an experimental material.

That is, storytelling video advertisements are classified into lecture video advertisements, drama video advertisements, real storytelling video advertisements, parody storytelling video advertisements and creative storytelling video advertisements according to the expression types. Among the five videos collected by item, one advertisement each was chosen and analyzed for this study.

In this paper, the following research questions 1 and 2 are examined by using survey and EEG (Electroencephalogram) experiment.

In order to proceed with this study, the research consists of six steps: observation of theoretical background, preliminary investigation, previous research, experimental design, experimental procedure, experimental research and survey verification. The theoretical background focused on domestic and foreign literature and existing research results.

The literature review examined not only the concept, characteristics and expression types of mobile storytelling video advertisement, but also the theoretical background of consumers' empathic response.

To measure the empathic response of consumers to mobile storytelling video advertisements, this study analyzed the responses of five advertisements through surveys and brain wave experiments.

EEG brain wave test can measure that consumers have brain wave response to 
elements of empathy with storytelling video advertisement. In this study, the experimental method was set up by presenting the experimental materials through preliminary investigation and previous studies focusing on EEG brain wave experiments.

For this purpose, the basic theory and measurement method of EEG brain wave test were described. Also, to select objective and accurate advertisement experiment, 5 mobile storytelling video advertisements were chosen by an expert group based on the expression type and the number of hits of the advertisement.

In the experimental research stage, the results of the EEG experiment and those of the empathetic response survey of the subjects were integrated and comprehensively evaluated to suggest what empathy response the mobile storytelling video advertisement causes to consumers and what brain wave response empathy has in the mobile storytelling video advertisement.

\section{Theoretical background}

\subsection{Definition and characteristics of storytelling}

Fig. 1 suggests that in storytelling, enjoyment of story in terms of participation, experience, and pleasure became a trait of story in that 'tell' and 'ing' as well as story itself become a dominant element and the transformation of traits in a story happens by various forms of 'tell' and 'ing.'

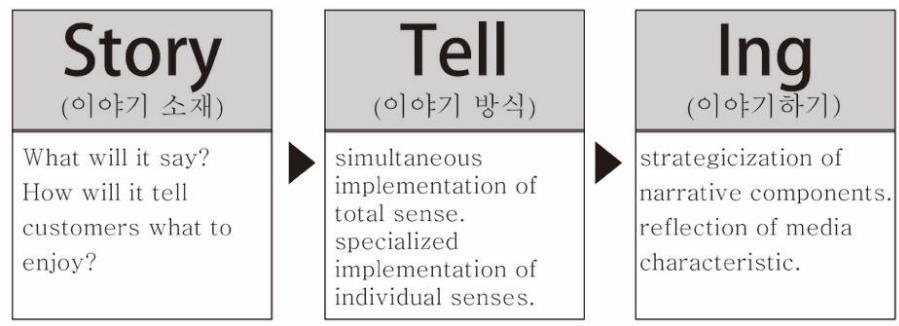

Fig. 1. Definition and characteristic of storytelling (Cho, 2012)

\subsection{Mobile storytelling video advertising}

\subsubsection{Definition and characteristics of mobile storytelling video advertising}

Mobile storytelling video advertising is a conceptual sum of digital media and storytelling, which means a story method suitable for new technologies. Unlike the expression method dealt with in traditional offline media, the core strategy of mobile storytelling video advertisement is positioned as a method of information exchange through voluntary empathy, so the strategy of acquiring empathy from customers should be prioritized. Therefore, the empathic response of consumers plays an important role in measuring the advertising effect in mobile storytelling video advertisements. Storytelling video advertisement is effective because it 
affects consumer emotion and moves consumer mind through unique story of the product. Therefore, more companies will create stories related to their brands and products over time and use storytelling video advertising (Chasuk, 2013)

\subsubsection{Types of expression in mobile storytelling video advertisement}

As for the expression type of advertisement with storytelling video advertisement, many researchers have presented various opinions about its content and form. As a result of examining previous studies, the types of expression in storytelling video advertisements differed slightly from researcher to researcher, but there were common points in the approach of story material development for storytelling. This study summarized the expression type of mobile storytelling video advertisement as Table 1.

Table 1: Types of Expression in Mobile Storytelling Video Advertisement

\begin{tabular}{|c|c|}
\hline Types of expression in Mobile Storytelling Video Advertisement \\
\hline \multirow{2}{*}{ morphological type } & lecture video advertising \\
\cline { 2 - 2 } & drama type video advertisement \\
\hline \multirow{2}{*}{ content type } & real storytelling video advertising \\
\cline { 2 - 2 } & parody storytelling video advertising \\
\cline { 2 - 2 } & creative storytelling video advertising \\
\hline
\end{tabular}

\subsection{Concept and form of empathy}

Empathy is what the observer who sees the emotion of the target person feels. (Chanming and Clara, 1996) Empathy doubles the effect by transporting consumers into situations in a story. Absorption (immersion) means that consumers move away from reality to the world of the story. It reduces negative cognitive reactions to advertisements, increases the realism of experience, and increases the persuasive effect of the story by causing strong emotional reactions by consumers.

As a result of many previous studies on storytelling video advertising and empathy, consumer's empathetic response to advertisement is a requirement for successful promotion. In the sense, it is particularly important to measure the empathic response in measuring the effect of storytelling video advertising.

\subsection{Empathic response elements of consumers}

Although there may be differences between the concept of empathy felt by consumers and the theoretical definition of researchers, empathy can be measured directly by consumers (Young and Hyo-jin, 2016). In this study, mobile storytelling video advertisements proved that it was found cognitive, emotional, affective, and authentic through the previous studies about factors that measure consumer's empathic response. Details are the same as table 2 (Hyeon, 2015)

As seen in Table 2, it is EEG experiment that suggests some evidence and logical 
basis used for testing hypotheses and influence of experimental results as to measurable matters on consumer's response in a meaningful way. Because the experiment compares the daily brain wave before stimulation and the brain wave after stimulation, it is possible to grasp the brain wave and the psychological part through the reaction of the brain. In addition, EEG experiment is an objective and scientific method, which can evaluate customer's practical emotion and response in terms of human being's emotion and cognition.

Table 2: Consumer's Empathic Response Elements of Consumer and Its Measurable Matters

\begin{tabular}{|c|c|}
\hline $\begin{array}{c}\text { Empathic } \\
\text { element }\end{array}$ & Measurable matters \\
\hline Cognitive & $\begin{array}{c}\text { Measurement of the Usefulness, Reliability, and perception of value as } \\
\text { information in Storytelling Advertisements }\end{array}$ \\
\hline Emotional & $\begin{array}{c}\text { Measurement of Consumers' Conscious, Unconscious Responses, Attitudes and } \\
\text { Behaviors }\end{array}$ \\
\hline Affective & The perception of pleasure and pleasure caused by advertisements \\
\hline Authentic & $\begin{array}{c}\text { Consumer's reactions to the things that can attract consumer attention and move } \\
\text { the mind }\end{array}$ \\
\hline
\end{tabular}

As for this problem, this study intends to analyze brain activities more practically and scientifically by conducting more scientific and in-depth investigation on brain activities through EGG measurement method of brain.

\section{Research model}

\subsection{Issue and model research}

Based on the theoretical contents above and literature research, this study conducted survey and EEG experiment on the effect of expression type of mobile storytelling video advertisement on customer's empathic response. The research model follows as Fig. 2. 


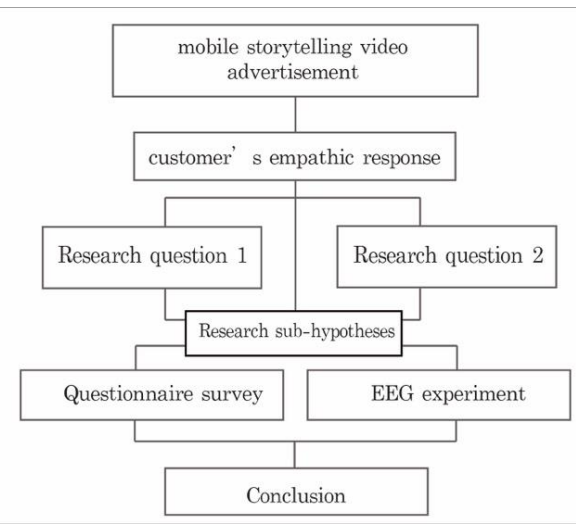

Fig. 2. Research model

The core of this study is to analyze the brain wave indicator of beta waves indicating consumer's empathic response through survey and EEG experiment. The goal of mobile storytelling video advertisement is to generate emotional response to consumers. To find out the empathic response of consumers to mobile storytelling video advertisement, the subject of this study set up two research questions and their sub-hypotheses based on previous studies.

1) Research question 1: What kind of empathic response does the expression type of mobile storytelling video advertisement cause to consumers?

H 1-1: Lecture-type advertisement of mobile storytelling video advertisement will have a significant effect on consumers.

H 1-2: Drama type advertisement of mobile storytelling video advertisement will have a significant effect on consumers.

H 1-3: Real storytelling advertisement of mobile storytelling video advertisement will have a significant effect on consumers.

H 1-4: The parody storytelling advertisement of mobile storytelling video advertisement will have a significant effect on consumers.

H 1-5: The creative storytelling advertisement of mobile storytelling video advertisement will have a significant effect on consumers.

H 1-6: The expression type of mobile storytelling video advertisement will have a significant effect on consumers' cognitive empathy, emotional empathy, affective empathy and authentic empathy.

2) Research question 2: What brain wave response will be shown in the mobile storytelling video advertisements in cognitive empathy, emotional empathy, affective empathy and authentic empathy?

H 2-1: Cognitive empathy, emotional empathy, affective empathy and authentic empathy will appear in the video commercials of mobile storytelling. 


\subsection{Methods of research and analysis}

\subsubsection{Research method}

Based on previous studies and literature reviews, this study measured the brain wave of the subjects limited to a small number of participants (5 30 or so) and to a small number of channels $(4 \sim 8)$. So, it does not measure the entire area of the brain. In this study, we obtained a lot of data by measuring 8-channel EEG and tried to get closer to objective results with 55 subjects. The more channels it has, the more location of measurement is verified, and the more detailed areas can be observed. Moreover, it is more advantageous to study human a priori EEG feature. EEG method is accessible in a nonmedical way and can measure the change in real time. Above all, it is an economical research method with the highest cost-effectiveness. This study adopted two stages of brain wave test and survey. The first stage is to measure and analyze the brain waves in an attempt to investigate the effects of mobile storytelling video advertisement on the empathic response to consumers. This study analyzed the changes in empathic response through EEG measurement to see how the brain waves appear that are the final integrated organs of all information and thus, investigated whether the EEG measurement method has the functionality to be used as a measurement tool for consumer empathic response.

In the second stage, the subjects who participated in the EEG measurement were surveyed through questionnaires about the experiences they felt while watching images during the experiment.

The data were statistically processed for the stored EEG data and the questionnaires obtained by combining the results of the EEG experiments and surveys. The statistical processing was done by a statistical package program, SPSS Ver.19.

\subsubsection{Contents of questionnaire}

This study analyzed cognitive, emotional, affective, and authentic empathy responses according to the expression type among mobile storytelling video advertisements. In addition, this study conducted a survey by constructing various variables such as components, expression types, and empathic responses along with the basics of the subjects surveyed in the experimental waiting room before the brain wave experiment. The questionnaire was made up in order to figure out whether the usual feelings and taste as the extra variables of empathic response have any correlation and mutual empathic response.

The measurement method was used by referring to the evaluation scale commonly used in previous research and the 5-point scale was used to measure. A total of 55 people were distributed 300 questionnaires, among which 275 questionnaires were selected as final samples. The survey items were as follows in Table 3. 
Table 3: Items of survey

\begin{tabular}{|c|c|c|}
\hline Variable & Question number & Measurement content \\
\hline \multirow{2}{*}{ Expression type } & 1 & preference \\
\cline { 2 - 3 } & 13 & feeling \\
\hline \multirow{3}{*}{ Empathic reaction } & 4 & cognitive response \\
\cline { 2 - 3 } & 5 & emotional and affective responses \\
\cline { 2 - 3 } & 4 & authentic response \\
\hline
\end{tabular}

\subsection{Selection of experimental objects among mobile storytelling advertisements}

In order to select the experimental objects used in the study, a preceding study was conducted. In this paper, EEG experiments and surveys on consumers' empathy responses were conducted for the advertisements selected by five categories.

First, mobile storytelling video advertisements were derived from those aired in Korea for four years from 2014 to 2017. Next, Through the preliminary survey of FGI (Focus group interview) target group interview. Focus Group Interview (2005) and based on the classification of the expression type of storytelling video advertisement, 25 out of the advertisements with more than one million views were selected and five were allocated for each five classification. One advertisement for each category was selected by experts as the object of experiment. Therefore, the study was conducted with 5 pieces, one for each type of expression of storytelling video advertisement. To select the final experiment, through the FGI method, 20 participants including expert groups were selected. They were given detailed concept of empathy and expression types before the preliminary survey. The final test of each expression type classification was selected by conducting a comprehensive evaluation of 20 subjects.

Based on the expression type and advertising strategy of storytelling video advertisement, each object has its own characteristics in the response and intensity of empathy. The final advertisements selected for the experiment are as follows in Table 4.

Table 4: Mobile Storytelling Advertisements Experimental Objects among

\begin{tabular}{|c|c|c|c|}
\hline Expression type & Advertising material & $\begin{array}{c}\text { Production } \\
\text { year }\end{array}$ & $\begin{array}{c}\text { Hit } \\
\text { number }\end{array}$ \\
\hline $\begin{array}{c}\text { Eecture-typed } \\
\text { video advertising }\end{array}$ & There is no perfection & 2016.07 .14 & $1,373,835$ \\
\hline $\begin{array}{c}\text { Drama type video } \\
\text { advertisement }\end{array}$ & $\begin{array}{c}\text { dentiste minimovie } \\
\text { a thirty-day promise }\end{array}$ & 2017.10 .15 & $1,810,433$ \\
\hline $\begin{array}{c}\text { real } \\
\text { Storytelling video } \\
\text { advertising }\end{array}$ & $\begin{array}{c}\text { Hyundai Motor Group Gift } \\
\text { Car-Season 7 Young } \\
\text { Entrepreneurship, Kim Ae-sun }\end{array}$ & 2016.11 .04 & $6,565,160$ \\
\hline $\begin{array}{c}\text { Parody storytelling video } \\
\text { advertising }\end{array}$ & Let's Enjoy, Practical-Sara & 2015.06 .15 & $6,370,566$ \\
\hline
\end{tabular}




\begin{tabular}{|c|c|c|c|}
\hline $\begin{array}{c}\text { Original } \\
\text { storytelling video } \\
\text { advertising }\end{array}$ & $\begin{array}{c}\text { Save the men who are in } \\
\text { hunger! } \\
\text { sneakers' emergency rescue }\end{array}$ & 2014.12 .25 & $6,945,790$ \\
\hline
\end{tabular}

\subsection{EEG Experiment}

The variation of the potential with unusual rhythm in the cerebral brain is called brainwave (Young, 2014). Brain-wave or EEG (electro-encephalography) is a flow of electricity that occurs when signals are transmitted between the brain nerves in the nervous system (Eun-Ju, 2016). It is the most important indicator of brain activity, which is different depending on the state of mind and body. In the brain response to five human senses (auditory, visual, tactile, olfactory, and gustatory), Seen as the research analysis that one-third of the cerebral cortex is responsible for visual stimulation and $70 \%$ of the cells involved in the senses recognize perception information by visual sense, it can be said that the details regarding stimulus, perception, awareness and response are derived or interpreted in the brain in a comprehensive way. As mentioned in the beginning, it is very meaningful to present the results of the EEG experiment as the basis for the academic impact or hypothesis verification. Currently, the EEG experiment is increasingly replacing a questionnaire in the evaluation of customer's use and experience in design related field.

In the experiment, the brain wave and the psychological part through the response of the brain can be grasped by measuring and comparing the daily brain wave before the stimulus and the brain wave after the stimulus. In addition, the existing previous studies can evaluate the emotions and responses to the real human emotions and cognitive domain through experiments with objective and scientific research methods rather than the research methods by analyzing questionnaire statistics and behavior.

Many advertisements are being studied as EEG experiment through previous studies. Despite of this, EEG experiments are also being used in the advertising field in Korea. This study is centered on empathic response to mobile storytelling video advertisements. As a scientific and objective way of research, the experiment was conducted using an electroencephalogram that can evaluate the emotions and cognitive responses of human cognition in the domain of emotion.

For convenience in analyzing the experimental results according to the universality of consumer empathy response effects, the subjects were tested from 20 s to 30 s, and a total of 55 subjects were selected. Demographically, 55 respondents analyzed were 29 males and 26 females, 35 in their 20 s and 20 in their 30 s. As of July 2017, the proportion of mobile internet users among the population aged 3 years or older was $88.5 \%$, and the ratio of men $(90.8 \%)$ was $4.7 \%$ higher than that of women $(86.1 \%)$, and the ratio of people was $99.8 \%$ in their $20 \mathrm{~s}$ and $99.8 \%$ in their 30 s. So the experimenter mainly tested people in their $20 \mathrm{~s}$ and $30 \mathrm{~s}$ (Ministry of Science and ICT, Korea Internet \& Security Agency, 2017). In order to 
improve heighten the reliability and accuracy of experimental results and avoid errors caused by fatigue on the subjects, one minute rest was conducted between the advertisements. The experimental tools are Laxtha's 8-channel QEEG equipment, model names PolyG-I and iPhone 6 Plus mobile phones. The experimental method is a combination of brain-wave testing and field surveys.

\section{Research analysis and results}

\subsection{Analysis on research question 1}

Research question 1 is what kind of empathy does the expression type of mobile storytelling video advertisement cause to consumers?

The research was focused on which type of advertisement subjects prefer and what kind of empathic response they made when they watch the 5 mobile storytelling video advertisements (the lecture type, drama type, real-storytelling, parody, original creation). The survey results are as follows.

First, the result of preference are as follows.

Table 5 showed that the preference of the type of expression of mobile storytelling video advertisement was $39.4 \%$ for drama type video advertisement, $20.0 \%$ for creative storytelling video advertisement, $18.2 \%$ for parody storytelling video advertisement, $13.4 \%$ for real storytelling video advertisement, and $9.1 \%$ for lecture type video advertisement. Therefore, among the types of mobile storytelling video advertisements, drama-type video advertisements are $39.4 \%$, which seems to be the most preferred by consumers.

Table 5: A Survey on the Preference of Mobile Storytelling Video Advertisement Expression Types

\begin{tabular}{|c|c|c|}
\hline Expression type & Advertising material & $\begin{array}{c}\text { Percentag } \\
\text { e (\%) }\end{array}$ \\
\hline Lecture video advertising & There is no perfection & $9.1 \%$ \\
\hline $\begin{array}{c}\text { Drama type video } \\
\text { advertisement }\end{array}$ & $\begin{array}{c}\text { Dentiste minimovie } \\
\text { a thirty-day promise }\end{array}$ & $39.4 \%$ \\
\hline $\begin{array}{c}\text { real } \\
\text { Storytelling video } \\
\text { advertising }\end{array}$ & $\begin{array}{c}\text { Hyundai Motor Group Gift Car } \\
\text { Season 7 Young Entrepreneurship - Kim Ae- } \\
\text { sun }\end{array}$ & $13.4 \%$ \\
\hline $\begin{array}{c}\text { Parody storytelling video } \\
\text { advertising }\end{array}$ & Let's Enjoy, Practical-Sara & $18.1 \%$ \\
\hline $\begin{array}{c}\text { Creation } \\
\text { storytelling video advertising }\end{array}$ & $\begin{array}{c}\text { Save the men who are in hunger! } \\
\text { sneakers emergency rescue }\end{array}$ & $20.0 \%$ \\
\hline
\end{tabular}

Next, as for what kind of empathic response are caused by the five types of advertisement, the results of survey are as follows.

1) The results of the survey of 'There is no perfection' advertisement are as follows. 
Table 6: Results of the advertisement 'There is no perfection'

\begin{tabular}{|c|c|c|c|c|c|c|c|}
\hline \multirow[t]{2}{*}{ Question } & \multirow[t]{2}{*}{$\begin{array}{l}\text { Feeling and } \\
\text { empathy }\end{array}$} & $\begin{array}{l}\text { Not react } \\
\text { strongly }\end{array}$ & $\begin{array}{c}\text { React } \\
\text { not } \\
\text { much }\end{array}$ & Neural & $\begin{array}{c}\text { Moderatel } \\
\text { y react }\end{array}$ & $\begin{array}{l}\text { Strongl } \\
\text { y react }\end{array}$ & \multirow[t]{2}{*}{$\begin{array}{c}\text { Avera } \\
\text { ge }\end{array}$} \\
\hline & & 1 & 2 & 3 & 4 & 5 & \\
\hline \multirow{3}{*}{$\begin{array}{c}\text { What did } \\
\text { you feel } \\
\text { about the } \\
\text { ad you } \\
\text { just saw? }\end{array}$} & cognitive feeling & $7.3 \%$ & $14.1 \%$ & $10.0 \%$ & $10.0 \%$ & $53.6 \%$ & 3.94 \\
\hline & $\begin{array}{c}\text { emotion and } \\
\text { emotion } \\
\text { exclamation }\end{array}$ & $7.9 \%$ & $12.4 \%$ & $13.9 \%$ & $10.3 \%$ & $55.5 \%$ & 3.93 \\
\hline & $\begin{array}{c}\text { feeling of } \\
\text { authenticity }\end{array}$ & $6.1 \%$ & $9.7 \%$ & $12.7 \%$ & $20.0 \%$ & $51.5 \%$ & 4.01 \\
\hline \multirow{3}{*}{$\begin{array}{c}\text { What } \\
\text { kind of } \\
\text { empathic } \\
\text { response } \\
\text { does the } \\
\text { ad just } \\
\text { seen } \\
\text { evoke? }\end{array}$} & $\begin{array}{c}\text { cognitive } \\
\text { empathic response }\end{array}$ & $8.6 \%$ & $15.0 \%$ & $13.6 \%$ & $13.6 \%$ & $49.1 \%$ & 3.80 \\
\hline & $\begin{array}{c}\text { emotional and } \\
\text { affective response }\end{array}$ & $6.2 \%$ & $11.6 \%$ & $12.4 \%$ & $11.6 \%$ & $58.2 \%$ & 4.04 \\
\hline & $\begin{array}{c}\text { authentic, } \\
\text { empathic response }\end{array}$ & $6.8 \%$ & $14.1 \%$ & $13.2 \%$ & $13.6 \%$ & $52.3 \%$ & 3.90 \\
\hline
\end{tabular}

As shown in Table 6, the results of the lecture type video advertisement of 'No Perfection' showed 53.6\% of cognitive feeling, 55.3\% of emotional and affective feeling, $51.5 \%$ of feeling of truth, $49.1 \%$ of cognitive empathic response, $58.2 \%$ of emotional and affective empathic response, $52.8 \%$ of authentic empathic reaction, and the average value of empathy was 3.80 4.04 high. And authentic empathy had a significant effect on consumers.

2) The results of the survey of 'dentiste minimovie- a thirty-day promise' advertisement are as follows.

Table 7: Results of 'dentiste mini movie a thirty-day promise'

\begin{tabular}{|c|c|c|c|c|c|c|c|}
\hline \multirow[t]{2}{*}{$\begin{array}{c}\text { Questi } \\
\text { on }\end{array}$} & \multirow[t]{2}{*}{$\begin{array}{l}\text { Feeling and } \\
\text { empathy }\end{array}$} & $\begin{array}{l}\text { Not react } \\
\text { strongly }\end{array}$ & $\begin{array}{c}\text { React } \\
\text { not } \\
\text { much }\end{array}$ & Neural & $\begin{array}{l}\text { Moderat } \\
\text { ely react }\end{array}$ & $\begin{array}{l}\text { Strongl } \\
\text { y react }\end{array}$ & \multirow[t]{2}{*}{$\begin{array}{l}\text { Ave } \\
\text { rage }\end{array}$} \\
\hline & & 1 & 2 & 3 & 4 & 5 & \\
\hline \multirow{3}{*}{$\begin{array}{c}\text { What } \\
\text { did you } \\
\text { feel } \\
\text { about } \\
\text { the ad } \\
\text { you } \\
\text { just } \\
\text { saw? }\end{array}$} & cognitive feeling & $7.3 \%$ & $10.9 \%$ & $10.0 \%$ & $14.1 \%$ & $57.7 \%$ & 4.04 \\
\hline & $\begin{array}{l}\text { emotion and } \\
\text { emotion } \\
\text { exclamation }\end{array}$ & $5.8 \%$ & $13.3 \%$ & $16.1 \%$ & $14.8 \%$ & $50.0 \%$ & 3.90 \\
\hline & feeling of truth & $5.5 \%$ & $12.7 \%$ & $10.9 \%$ & $20.6 \%$ & $50.3 \%$ & 3.98 \\
\hline \multirow{2}{*}{$\begin{array}{l}\text { What } \\
\text { kind of } \\
\text { empath } \\
\text { y does }\end{array}$} & $\begin{array}{c}\text { cognitive } \\
\text { empathic response }\end{array}$ & $8.2 \%$ & $14.1 \%$ & $11.8 \%$ & $16.4 \%$ & $49.5 \%$ & 3.85 \\
\hline & $\begin{array}{c}\text { emotional and } \\
\text { affective response }\end{array}$ & $4.7 \%$ & $12.0 \%$ & $14.9 \%$ & $16.0 \%$ & $52.4 \%$ & 3.99 \\
\hline
\end{tabular}




\begin{tabular}{|c|c|c|c|c|c|c|c|}
\hline $\begin{array}{c}\text { the ad } \\
\text { just } \\
\text { seen } \\
\text { evoke? }\end{array}$ & $\begin{array}{c}\text { authentic } \\
\text { empathic response }\end{array}$ & $5.9 \%$ & $18.2 \%$ & $12.3 \%$ & $12.3 \%$ & $51.4 \%$ & 3.85 \\
\hline
\end{tabular}

As for the Table 7, the results of the 'Dentiste Mini-movie: A thirty-day Promise' drama-type video advertisement showed $57.7 \%$ of cognitive feeling, $50.0 \%$ of emotional and affective feeling, $50.3 \%$ of feeling of truth, $49.5 \%$ of cognitive empathic reaction, $52.4 \%$ of emotional and affective empathy reaction, and $51.4 \%$ of authentic, empathic reaction. Emotional empathy, emotional empathy and authentic empathy have a significant effect on consumers.

3) The results of the advertisement of 'Hyundai Motor Group Gift Car Sseason 7: Young Entrepreneur - Kim Ae Sun' are as follows.

As for the result of Table 8, the results of the 'Hyundai Motor Group Gift Car Sijon 7 Young Entrepreneurship - Kim Ae Sun' real storytelling video advertisement showed $52.3 \%$ of cognitive feeling, 54.8\% of emotional and affective feeling, $49.1 \%$ of truth feeling, $51.8 \%$ of cognitive empathy, $53.8 \%$ of emotional and affectivel empathy, and $51.8 \%$ of authentic empathy response, and the average empathy was 3.87 3.98. Cognitive empathy, emotional empathy, affective empathy and authentic empathy of real storytelling video advertisements have a significant effect on consumers.

Table 8: The results of the advertisement of 'Hyundai Motor Group Gift Car Sseason 7: Young Entrepreneur - 'Kim Ae Sun'

\begin{tabular}{|c|c|c|c|c|c|c|c|}
\hline \multirow{2}{*}{ Question } & $\begin{array}{c}\text { Feeling and } \\
\text { empathy }\end{array}$ & $\begin{array}{c}\text { Not react } \\
\text { strongly }\end{array}$ & $\begin{array}{c}\text { React } \\
\text { not } \\
\text { much }\end{array}$ & Neural & $\begin{array}{c}\text { Moderatel } \\
\text { y react }\end{array}$ & $\begin{array}{c}\text { Strong } \\
\text { ly } \\
\text { react }\end{array}$ & $\begin{array}{c}\text { Avera } \\
\text { ge }\end{array}$ \\
\cline { 3 - 7 } & 1 & 2 & 3 & 4 & 5 & \\
\hline $\begin{array}{c}\text { What did you } \\
\text { feel about the } \\
\text { ad you just } \\
\text { saw? }\end{array}$ & $\begin{array}{c}\text { cognitive feeling } \\
\text { emotional and } \\
\text { affective feeling }\end{array}$ & $6.8 \%$ & $10.0 \%$ & $14.1 \%$ & $16.8 \%$ & $52.3 \%$ & 3.98 \\
\cline { 2 - 7 } & feeling of truth & $7.3 \%$ & $13.0 \%$ & $13.3 \%$ & $11.5 \%$ & $54.8 \%$ & 3.94 \\
\hline \multirow{2}{*}{$\begin{array}{c}\text { What kind of } \\
\text { empathy does } \\
\text { the ad just } \\
\text { seen evoke? }\end{array}$} & $\begin{array}{c}\text { empathic response } \\
\text { affective empathy }\end{array}$ & $8.6 \%$ & $10.5 \%$ & $17.7 \%$ & $11.4 \%$ & $51.8 \%$ & 3.87 \\
\cline { 2 - 7 } response & $\begin{array}{c}\text { true } \\
\text { empathic response }\end{array}$ & $5.5 \%$ & $16.0 \%$ & $9.1 \%$ & $15.6 \%$ & $53.8 \%$ & 3.96 \\
\hline
\end{tabular}

4) The results of the survey of 'Enjoy, Practical -'sara' advertisement are as follows.

Table 9: The results of the survey of 'Enjoy, Practical -'sara'

\begin{tabular}{|l|c|c|c|c|c|c|c|} 
Question & Feeling and & Not react & React & Neural & Moderat & Strongly & Avera \\
\hline
\end{tabular}




\begin{tabular}{|c|c|c|c|c|c|c|c|}
\hline & empathy & strongly & $\begin{array}{c}\text { not } \\
\text { much }\end{array}$ & & ely react & react & ge \\
\cline { 3 - 7 } & 1 & 2 & 3 & 4 & 5 & \\
\hline $\begin{array}{c}\text { What did } \\
\text { you feel } \\
\text { about the ad } \\
\text { you just } \\
\text { saw? }\end{array}$ & $\begin{array}{c}\text { cognitive } \\
\text { feeling }\end{array}$ & $6.8 \%$ & $10.0 \%$ & $14.1 \%$ & $16.8 \%$ & $52.3 \%$ & 3.98 \\
\cline { 2 - 7 } & $\begin{array}{c}\text { emotional and } \\
\text { affective feeling }\end{array}$ & $7.3 \%$ & $13.0 \%$ & $13.3 \%$ & $11.5 \%$ & $54.8 \%$ & 3.94 \\
\cline { 2 - 7 } feeling of truth & $7.3 \%$ & $13.3 \%$ & $10.9 \%$ & $19.4 \%$ & $49.1 \%$ & 3.90 \\
\hline $\begin{array}{c}\text { cognitive } \\
\text { empathic } \\
\text { What kind } \\
\text { of empathy } \\
\text { does the ad } \\
\text { just seen } \\
\text { evoke? }\end{array}$ & $\begin{array}{c}\text { emotional and } \\
\text { affective } \\
\text { empathic } \\
\text { response }\end{array}$ & $8.6 \%$ & $10.5 \%$ & $17.7 \%$ & $11.4 \%$ & $51.8 \%$ & 3.87 \\
\cline { 2 - 7 } & $\begin{array}{c}\text { true } \\
\text { empathic } \\
\text { response }\end{array}$ & $5.0 \%$ & $13.2 \%$ & $14.1 \%$ & $15.9 \%$ & $51.8 \%$ & 3.96 \\
\hline
\end{tabular}

As for the results of Table 9, results show that 'Let's enjoy, practical-'sara' parody storytelling video advertisements are 50.5\% cognitive feeling, 52.1\% emotional and affective feeling, $56.4 \%$ feeling of truth, $50.5 \%$ cognitive empathy, $55.3 \%$ emotional and affective empathy, and $56.4 \%$ authentic empathy. Empathy has a significant effect on consumers.

5) The findings of the "Save those who are in hunger! Snickers Emergency Rescue" advertisement are as follows.

Table 10: The findings of the "Save those who are in hunger! Snickers Emergency

Rescue" advertisement

\begin{tabular}{|c|c|c|c|c|c|c|c|}
\hline \multirow[t]{2}{*}{ Question } & \multirow[t]{2}{*}{$\begin{array}{l}\text { Feeling and } \\
\text { empathy }\end{array}$} & $\begin{array}{l}\text { Not react } \\
\text { strongly }\end{array}$ & $\begin{array}{l}\text { Rreact } \\
\text { not } \\
\text { much }\end{array}$ & Neural & $\begin{array}{l}\text { Moder } \\
\text { ately } \\
\text { react }\end{array}$ & $\begin{array}{l}\text { Strong } \\
\text { ly } \\
\text { react }\end{array}$ & \multirow[t]{2}{*}{$\begin{array}{l}\text { Avera } \\
\text { ge }\end{array}$} \\
\hline & & 1 & 2 & 3 & 4 & 5 & \\
\hline \multirow{3}{*}{$\begin{array}{l}\text { What did you } \\
\text { feel about the } \\
\text { ad you just } \\
\text { saw? }\end{array}$} & cognitive feeling & $7.7 \%$ & $13.6 \%$ & $11.8 \%$ & $11.8 \%$ & $55.0 \%$ & 3.93 \\
\hline & $\begin{array}{l}\text { emotional and } \\
\text { affective feeling }\end{array}$ & $7.6 \%$ & $13.0 \%$ & $13.9 \%$ & $14.5 \%$ & $50.9 \%$ & 3.88 \\
\hline & feeling of truth & $5.5 \%$ & $10.9 \%$ & $12.7 \%$ & $10.9 \%$ & $60.0 \%$ & 4.09 \\
\hline \multirow{3}{*}{$\begin{array}{l}\text { What kind of } \\
\text { empathy does } \\
\text { the ad just } \\
\text { seen evoke? }\end{array}$} & $\begin{array}{l}\text { cognitive } \\
\text { empathic response }\end{array}$ & $3.6 \%$ & $17.3 \%$ & $14.1 \%$ & $14.1 \%$ & $50.9 \%$ & 3.91 \\
\hline & $\begin{array}{l}\text { emotional and } \\
\text { affective empathic } \\
\text { response }\end{array}$ & $2.5 \%$ & $18.5 \%$ & $14.5 \%$ & $9.5 \%$ & $54.9 \%$ & 3.96 \\
\hline & $\begin{array}{l}\text { authentic, } \\
\text { empathic response }\end{array}$ & $5.0 \%$ & $11.8 \%$ & $13.2 \%$ & $17.7 \%$ & $52.3 \%$ & 4.00 \\
\hline
\end{tabular}


Table 10 shows that 'Save them who are in hunger!, Snickers Emergency Rescue 'creative storytelling video advertisements showed $55.0 \%$ of cognitive feeling, $50.9 \%$ of emotional and affective feeling, $60.6 \%$ of feeling of truth, $50.9 \%$ of cognitive empathy, $54.9 \%$ of emotional and affective empathy, and $52.3 \%$ of authentic empathy. Because average of empathy response was high with 3.88 to 4.09 , it is found that cognitive response, emotional response, affective response, and authentic response has a significant effect on consumers.

As for research question 1, or what kind response customers makes on expression type of mobile storytelling response, the analysis results showed that the drama type video advertisement was the most preferred to the consumers. And the lecture type video advertisement, drama type video advertisement, real storytelling video advertisement, parody storytelling video advertisement, and original storytelling advertisement had a significant effect on consumers in terms of cognitive empathy, emotional empathy, affective empathy, authentic empathy.

\subsection{Analysis on research question 2}

Research question 2 is what brain wave response will be shown in the mobile storytelling video advertisements with cognitive empathy, emotional empathy, affective empathy and authentic empathy.

The results of brain wave measurement by mobile storytelling video advertisement are examined in detail and summarized as follows.

Table: 11. Brain-wave Measurement Results by Mobile Storytelling Image

Advertisement

\begin{tabular}{|c|c|c|c|c|c|c|}
\hline \multirow[b]{2}{*}{$\begin{array}{l}\text { Advertisin } \\
\mathrm{g} \text { material }\end{array}$} & $\begin{array}{l}\text { Lecture } \\
\text { type } \\
\text { video } \\
\text { advertising }\end{array}$ & $\begin{array}{l}\text { Drama } \\
\text { type } \\
\text { video } \\
\text { advertisin } \\
\text { g }\end{array}$ & $\begin{array}{l}\text { Real } \\
\text { storytelling } \\
\text { video } \\
\text { advertising }\end{array}$ & $\begin{array}{l}\text { Parody } \\
\text { storytelling } \\
\text { video } \\
\text { advertising }\end{array}$ & $\begin{array}{l}\text { Original } \\
\text { storytelling } \\
\text { video } \\
\text { advertising }\end{array}$ & \\
\hline & $\begin{array}{l}\text { There is no } \\
\text { perfection }\end{array}$ & $\begin{array}{l}\text { dentiste } \\
\text { minimovie }\end{array}$ & $\begin{array}{l}\text { Hyundai } \\
\text { Motor } \\
\text { Group } \\
\text { gift car }\end{array}$ & $\begin{array}{l}\text { Let's enjoy } \\
\text { it, } \\
\text { Paractical } \\
\text { sara }\end{array}$ & $\begin{array}{l}\text { sneakers } \\
\text { emergency } \\
\text { rescue }\end{array}$ & $\begin{array}{l}\text { brain } \\
\text { wave } \\
\text { with } \\
\text { no } \\
\text { stimu } \\
\text { lus }\end{array}$ \\
\hline Fp1 & $0.59 \pm 0.15$ & $0.58 \pm 0.14$ & $0.58 \pm 0.14$ & $0.59 \pm 0.14$ & $0.59 \pm 0.15$ & $\begin{array}{l}0.49 \pm \\
0.11\end{array}$ \\
\hline Fp2 & $0.61 \pm 0.12$ & $0.61 \pm 0.11$ & $0.60 \pm 0.12$ & $0.61 \pm 0.12$ & $0.61 \pm 0.13$ & $\begin{array}{l}0.51 \pm \\
0.09\end{array}$ \\
\hline F3 & $0.36 \pm 0.09$ & $0.37 \pm 0.08$ & $0.36 \pm 0.08$ & $0.36 \pm 0.08$ & $0.35 \pm 0.08$ & $\begin{array}{l}0.23 \pm \\
0.06\end{array}$ \\
\hline F4 & $0.37 \pm 0.10$ & $0.38 \pm 0.08$ & $0.36 \pm 0.09$ & $0.37 \pm 0.08$ & $0.36 \pm 0.08$ & $\begin{array}{l}0.24 \pm \\
0.05\end{array}$ \\
\hline $\mathrm{T} 3$ & $0.19 \pm 0.09$ & $0.22 \pm 0.09$ & $0.20 \pm 0.09$ & $0.20 \pm 0.09$ & $0.19 \pm 0.10$ & $\begin{array}{l}0.12 \pm \\
0.06\end{array}$ \\
\hline $\mathrm{T} 4$ & $0.16 \pm 0.10$ & $0.21 \pm 0.12$ & $0.17 \pm 0.11$ & $0.17 \pm 0.11$ & $0.15 \pm 0.10$ & $0.10 \pm$ \\
\hline
\end{tabular}




\begin{tabular}{|l|l|l|l|l|l|l|}
\hline P3 & $0.17 \pm 0.08$ & $0.18 \pm 0.08$ & $0.17 \pm 0.08$ & $0.17 \pm 0.09$ & $0.17 \pm 0.08$ & $\begin{array}{l}0.13 \pm \\
0.05\end{array}$ \\
\hline P4 & $0.15 \pm 0.09$ & $0.17 \pm 0.10$ & $0.16 \pm 0.08$ & $0.17 \pm 0.09$ & $0.16 \pm 0.08$ & $\begin{array}{l}0.13 \pm \\
0.06\end{array}$ \\
\hline
\end{tabular}

As shown in Table 11, the result of EEG measurement can be seen as RB (beta wave) by advertisement. Therefore, cognitive empathy, emotional empathy, affective empathy and authentic empathy in mobile storytelling video advertisements show RB (beta wave).

The table above shows that the $\mathrm{RB}$ (beta wave) brain wave Fp1 and Fp2 of the lecture video advertisement titled "There is no perfection: Kang Soo-jin" are 0.59, 0.61 , and the $\mathrm{RB}$ (beta wave) brain wave Fp1 and Fp2 of the drama video advertisement "Deniste mini movie: A thirty-day promise" are 0.58, 0.61. The RB (beta wave) brain wave Fp1 and Fp2 of the real storytelling video advertisement 'Hyundai Motor Group Gift Car Season 7: Young Entrepreneurship - Kim Ae Sun' were $0.58,0.60$. Brain wave Fp1 and Fp2 of the parody storytelling video advertisements 'Let's enjoy' RB (beta wave) were 0.59, 0.61. Besides, original storytelling video advertisement, "Save those who are in hunger (SNICKERS Hungry Rescue) recorded 0.59 and 0.61 in its Fp1 and Fp2.

The RB (beta wave) brain waves Fp1 and Fp2 of the five advertisements were higher than the brain waves of the non-stimulation, and the absorption rate was also high. So it can be seen that it has a great influence on the empathic response. $\mathrm{RB}$ (Beta wave) appears in the mental activities such as concentration of attention. Therefore, empathy in mobile storytelling video advertisements is more intense to consumers through objective brain wave measurement.

\subsection{Results}

Research Question 2 is what brain wave response will be shown in the mobile storytelling video advertisements with cognitive empathy, emotional empathy, affective empathy and authenticity empathy. The results of the analysis show that cognitive empathy, emotional empathy, affective empathy and authentic empathy in mobile storytelling video advertisements have a beta wave. So they have a significant impact on consumers.

The results of each advertisement were summarized as Fig. 3. 


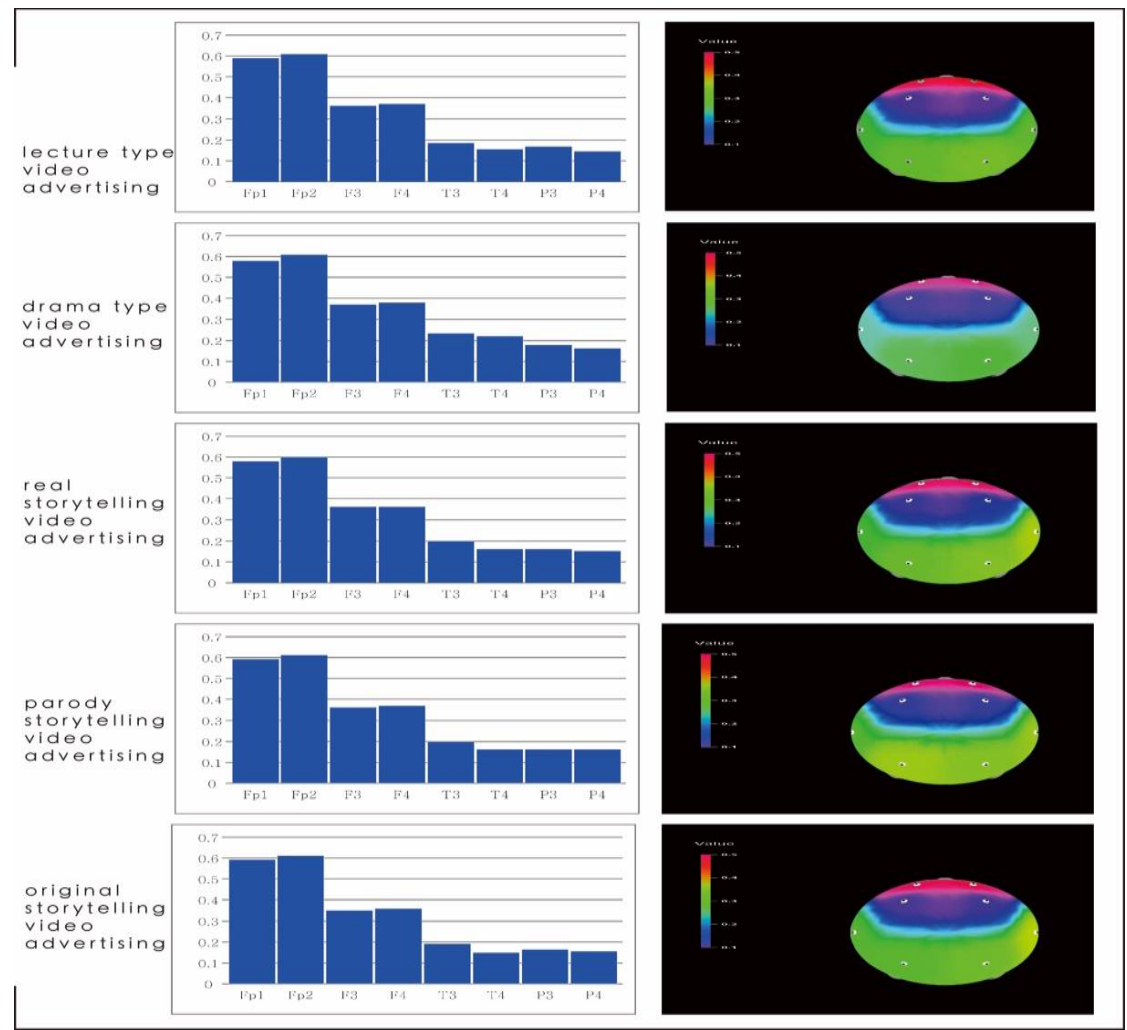

Fig. 3. The Graph of beta waves and activity rate of 5 advertisements

Figure 3 shows that the beta wave graphs of each advertisement are highly activated when stimulated in Fp1 and Fp2, and therefore have a significant effect on the empathy of consumers.

Based on this, empathy has a positive effect on mobile storytelling video advertising. The results of the survey are consistent with the results of the survey; "cognitive empathy, emotional empathy, affective empathy and authentic empathy out of lecture video advertising, drama video advertising, real storytelling video advertising, parody storytelling video advertising, and original storytelling video advertising will have a significant impact on consumers."

\section{Conclusion}

Based on the precedent studies that consumers' empathic response plays an important role in the advertisement effect of mobile storytelling video advertisement, this study aims to verify the fact that empathic response should be measured when evaluating the advertisement response of mobile storytelling video advertisement.

The results of this study show that there is a certain type of expression which consumers prefer according to their brand characteristics. The most preferred type 
of mobile storytelling video advertisement was the drama type video advertisement. The problems raised in the research question 1 of this paper were solved by proving that the level of empathic understanding of mobile storytelling video advertisements has a positive effect on consumers' cognitive response, emotional and affective empathy response and authentic empathy response.

Observation of research question 1 proves that among the types of expression of mobile storytelling video advertisement, drama type video advertisement is the highest value for consumers with $39.4 \%$, and drama type video advertisement is the most preferred among the research hypothesis 1-1 to 1-5. The average value of cognitive empathy, emotional empathy, affective empathy and authentic empathy of lecture video advertisement, drama video advertisement, real storytelling video advertisement, parody storytelling video advertisement, and creative storytelling video advertisement was 3.80 4.09, which is quite high. And the research hypothesis 1-6 showed that cognitive empathy, emotional empathy, affective empathy and authentic empathy of each expression type had a significant effect on consumers.

Finally, the EEG test showed that beta waves were active in two measurement positions, Fp1 and Fp2, and the level of empathic understanding of mobile storytelling video advertisements was found to be beta waves in consumers' cognitive empathic responses, emotional and affective empathic responses, and authentic empathic responses.

Research question 2 is that the cognitive empathy, emotional empathy, emotional empathy and authentic empathy in mobile storytelling video advertisements are shown to be the red and purple of the beta wave Fp1 and Fp2, and the figure is $0.58 \sim 0.61$, so the research hypothesis $2-1$ proved to have a significant effect on consumers.

In sum, it can be seen that mobile storytelling video advertisement will have a significant impact on consumers' empathy response.

Empathic response has a significant effect on storytelling advertising, and thus it is a useful evaluation factor to be measured in the evaluation of consumer's empathy response for advertising effect prediction. The importance of consumer empathy in mobile storytelling video advertising suggests that practitioners who want to use storytelling video advertising to conduct advertising campaigns should consider whether consumers acquire empathy responses.

The advertising practitioner who wants to produce effective advertisement should look into whether the advertisement contains elements that can lead to the empathic response of consumers when producing advertisements, and examine whether the mobile storytelling video advertisement successfully forms a consensus with consumers by measuring the empathic response in the preliminary effect survey of advertisements.

Afterwards, in the market of emotional marketing, advertisements using 
storytelling can be expected to serve as a tool to improve the image of the brand as well as to create effective communication and consensus with consumers. In that sense, marketing strategies should be established by utilizing storytelling video advertisements that match the tendency of each brand and consumer.

\section{Acknowledgments}

This study was completed by modifying the $2019 \mathrm{PhD}$ dissertation of ZOU KANG (the author).

\section{References}

Chanming D. and Clara H. (1996). The Current State of Empathy Research. Journal of Counseling Psychology, 43(3), pp.261-27.

Chasuk J. (2013).(A)study on the influence of message components of storytelling advertising and involvement on advertising effects. Graduate School of Hanyang University, Doctoral thesis, 22.

Cho K. (2012). A study on advertising applied storytelling technique. Journal of Communication Design, 39, 43-53.

MalKum H., MyeongSik R. and YoulHong S. (2016). Moderating effect of the consumers' need for uniqueness and self-regulatory focus in the advertising effect of storytelling advertisement. The Korean Journal of Advertising, 27(6), 97-127.

HeeLee M. (2016). Emotional storytelling advertising of digital emotion era. The Society of Korea Illusart, 19(1), 203-211.

Eun-Ju N. (2016) On an ERP experimental study of metalinguistic negation: A reply to Lee(2015), The Discourse and Cognitive Linguistics Society of Korea, Vol.23 No.1, p.89-109.

FGI(Focus Group Interview)(2005). This is an expert interview survey method for homogeneous experts in a way that acquires the knowledge and information they want to know by conducting free discussions with a specific topic for a group of respondents with expertise. Source: Chae Seo-il, marketing research, b\&abook, p.171.

Hyeon J. S. (2015) Consumer Responses to Storytelling Advertising:Investigating the Power of Empathic Response , The Korean Journal of Advertising, Vol.26 
No.7 , pp.59-79.

Ministry of Science and ICT, Korea Internet \& Security Agency, (2017) 2017 Internet Usage Survey Summary Report, p.10.

Young K. S. and Hyo-jin K. (2016) The Effect of Brand Story Type on Consumer Empathy Towards Advertising: Moderating Role of Product Type, The Academy of Customer Satisfaction Management, Vol.18 No3, p.27.

Young L. J. (2014) A Cognitive Effect of David Ogilvy's Advertising Design and Modern Advertising Demonstrated through EEG, Department of Industrial Design, The Graduate School, Pukyong National University, Doctoral thesis, p.49. 